\title{
A Qualitative Study of Family Forest Owners' Experiences with Timber Transactions
}

\author{
Adam Maltempie
}

Follow this and additional works at: https://researchrepository.wvu.edu/etd

\section{Recommended Citation}

Maltempie, Adam, "A Qualitative Study of Family Forest Owners' Experiences with Timber Transactions" (2017). Graduate Theses, Dissertations, and Problem Reports. 6151.

https://researchrepository.wvu.edu/etd/6151

This Thesis is protected by copyright and/or related rights. It has been brought to you by the The Research Repository @ WVU with permission from the rights-holder(s). You are free to use this Thesis in any way that is permitted by the copyright and related rights legislation that applies to your use. For other uses you must obtain permission from the rights-holder(s) directly, unless additional rights are indicated by a Creative Commons license in the record and/ or on the work itself. This Thesis has been accepted for inclusion in WVU Graduate Theses, Dissertations, and Problem Reports collection by an authorized administrator of The Research Repository @ WVU. For more information, please contact researchrepository@mail.wvu.edu. 


\title{
A Qualitative Study of Family Forest Owners' Experiences \\ With Timber Transactions
}

\author{
Adam Maltempie \\ Thesis submitted to the \\ Davis College of Agriculture, Natural Resources, and Design \\ at West Virginia University \\ in partial fulfilment of the requirements for the degree of \\ Master of Science \\ in \\ Forestry
}

David W. McGill, Ph.D., Chair

Ben D. Spong, Ph.D.

Kathryn Arano Gazal, Ph.D.

Emily Perdue, Ph.D.

Division of Forestry

Morgantown, West Virginia

2017

Keywords: Family Forest Owners, Timber Transaction Process, Focus Groups Copyright 2017 Adam Maltempie 


\section{ABSTRACT \\ A Qualitative Study of Family Forest Owners' Experiences With Timber Transactions}

\section{Adam Maltempie}

The majority of forestland in America is privately owned. Family forest owners own $62 \%$ of all private forestland in America. In West Virginia, family forest owners own 6.5 million acres (53\%) of all forestland in the state. Timber harvesting from these family forests is crucial to both West Virginia's and the United States' timber industry. We examined family forest owners' experiences during the complex timber transaction process. This process covers the time from when the landowner decides to sell timber until all harvest, legal, and financial aspects are completed. We conducted a focus group with nine participants representing eight different family owned forests in West Virginia, who were recently involved in a timber transaction. In this focus group, five main themes emerged that affect timber transaction experiences. These include, Decision for the Sale, Peoples' Involvement During the Sale, Knowledge about Selling Timber, Trust of People and Legal Aspect in Selling Timber. These findings will help inform future family forests owners about how to achieve successful and satisfactory timber transactions. The information gained will also help in the creation of a future mailed questionnaire designed to capture family forest owners' experiences during the timber transaction process. 


\section{ACKNOWLEDGEMENTS}

I would like to thank my advisor Dr. Dave McGill and my committee members Dr. Ben Spong and Dr. Kathryn Gazal for their advice and feedback, and Dr. Emily Perdue for helping me with the methodology and data analysis for this project.

Thanks to Dr. Jason McKibben for his help with moderating the focus groups and advice on data analyses.

I would also like to thank all the participants that were involved in this study.

Without your participation this project could not have been completed.

Lastly, I would like to thank the Appalachian Hardwood Center for providing the funding for this project. 


\section{TABLE OF CONTENTS}

Acknowledgements .....................................................................................................ii

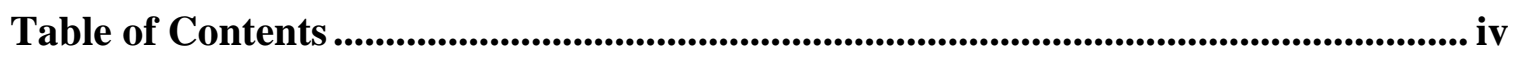

List of Figures........................................................................................................................................ vi

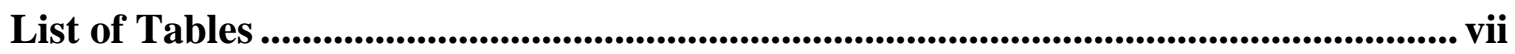

Chapter I: Introduction............................................................................................................... 1

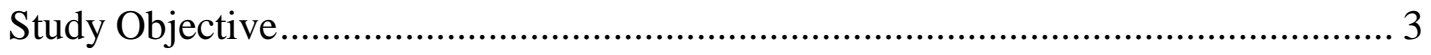

Chapter II: Review of Literature ................................................................................................. 5

Family Forest Owners................................................................................ 5

Timber Transaction Process................................................................................... 7

Customer Satisfaction ........................................................................................ 13

Focus Group Interviewing .......................................................................... 16

Chapter III: Methodology .............................................................................................. 18

Design of the Study Phase I: Recruiting Family Forest Owners .............................. 19

Phase II: Data Collection Focus Group Interviewing ............................................... 22

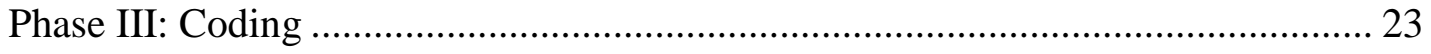

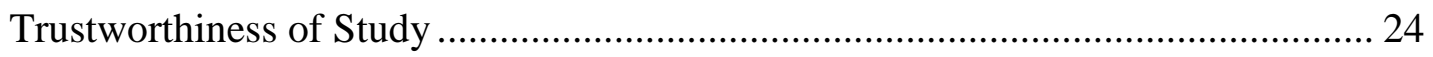

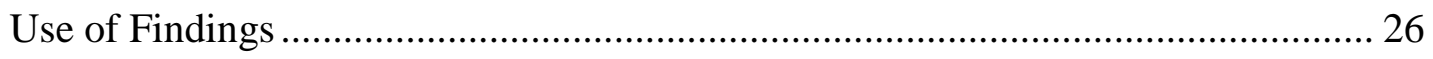

Chapter IV: Results ....................................................................................................................... 27 
Postcard Response and Cooperation Rates

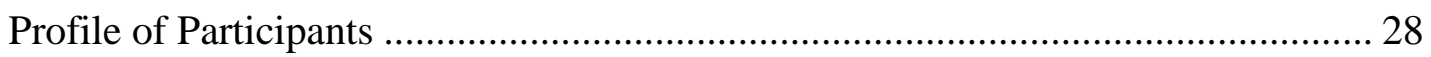

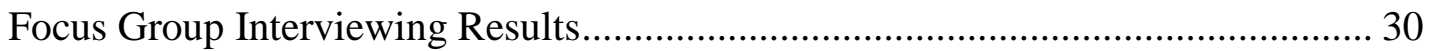

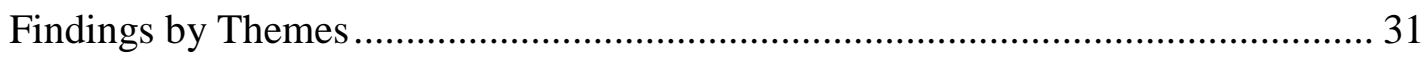

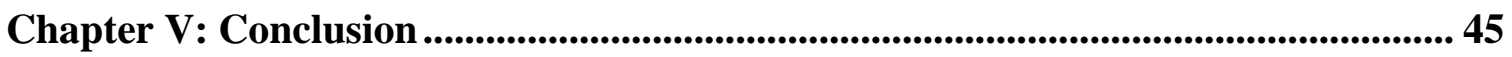

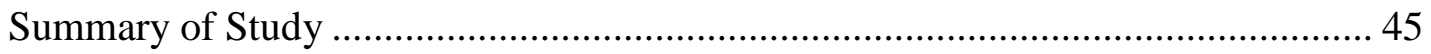

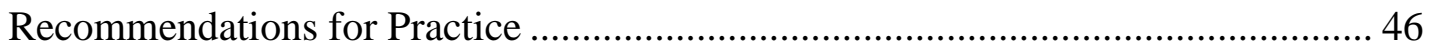

Recommendations for Future Research ..................................................... 47

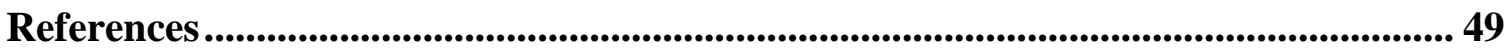

Appendix A: Recruitment Cover-Letter........................................................................... 55

Appendix B: Recruitment Postcard .............................................................................. 56

Appendix C: Reminder/Thank You Letter .................................................................... 57

Appendix D: Focus Group Questions ................................................................................ 58

Appendix E: Demographic Background Questions................................................ 59 


\section{LIST OF FIGURES}

$\begin{array}{lll}\text { Figure } \quad \text { Title } & \text { Page }\end{array}$

Figure 1. Four Party Scenario Timber Transaction Process. Figure courtesy of D. McGill, West Virginia University Extension Service............................................................. 12

Figure 2. Three Party Scenario Timber Transaction Process. Figure courtesy of D.

McGill, West Virginia University Extension Service........................................................ 12

Figure 3. Combining qualitative and quantitative research, (Grigoroudis and Siskos,

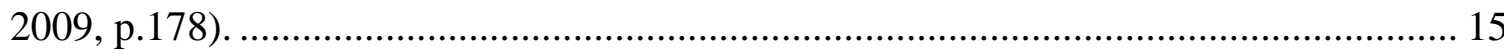

Figure 4. Relationship of Categories and their Influence on Landowner Experience..... 42 


\section{LIST OF TABLES}

Table Title $\quad$ Page

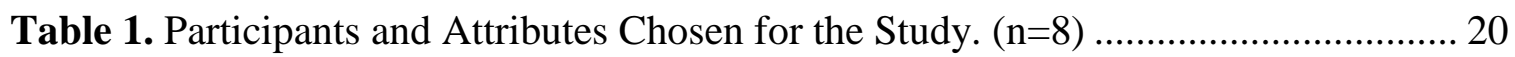

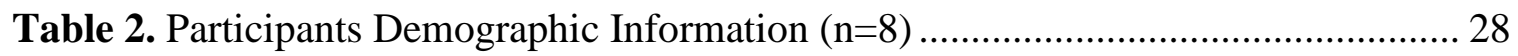

Table 3. Five main themes and list of attributes that influence family forest owners'

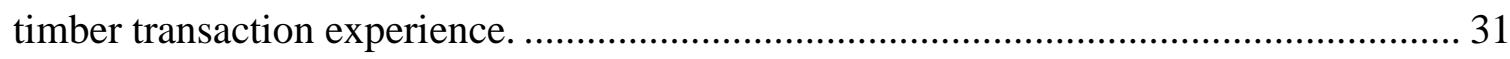




\section{Chapter I: Introduction}

Most forestlands in America are privately owned. There are roughly 751 million acres of forestland in the United States of which fifty-six percent is privately owned. Within the ownership category of private forestland, 62 percent is owned by families and individuals and are frequently referred to as "family forests" (United States Department of Agriculture, 2008; Butler, 2008 and Butler, 2012). In the United States most family forests are 10 acres or less (Butler, 2010). Despite the fact that most of the forestlands in America are owned by families and individuals, many of these owners do not realize they own forestland, because when people think of forestland they think of state and federally owned lands (Butler, 2015).

Among all 50 U.S. states, West Virginia ranks third highest in percent forest cover. Nearly 12 million acres, or 78 percent of the state's landscape is forested (Childs, 2005). Out of the 12 million acres of forestland in West Virginia 10.6 million or 87 percent are privately owned (Widmann, 2014). What is even more significant is the percentage of West Virginia's forestland owned by private family forest owners. Family forest owners make up 6.5 million acres or 53 percent of all forestland in West Virginia. With over half of West Virginia's forestland owned by family forest owners, decisions made by these landowners can greatly influence the future of West Virginia's forest (Widmann, 2014). These forestlands owned by family forest owners are a very important part of the social, environmental, and economical fabric of West Virginia's landscape. Social benefits these forestlands provide include: recreational activities, aesthetics, and primary residence. These forestlands are also very beneficial to the environment, providing wildlife habitat, removal of carbon dioxide from the air, and contribute to 
water quality and supply (Widmann, 2014; Widmann et al., 2012; Bengston, Asah, \& Butler, 2011). Forestlands owned by family forest owners are also a very important part of the state's economy. Economic benefits from these forests include: timber harvesting, farming, and taxes generated form recreational activities (Bengston et al., 2011; Childs, 2005).

Family forest owners have diverse and multidimensional motives for owning land (Bengston, et al., 2011). One of the reasons for owning forestland is timber production. Timber production ranked $10^{\text {th }}$ of 12 categories in the 2006 National Woodland Owner Survey (NWOS) (Butler, 2012; Bengston, et al., 2011). Even though timber production is not a primary reason of family forest ownership, it becomes very important to a landowner when they decide to sell timber.

Numerous studies have been conducted that focused on the economic aspects of timber harvesting (e.g., Leffler and Rucker, 1991; Childs, 2005; Joshi and Arano, 2009; Demchik, Conrad, and Vokoun, 2016). The effects of timber harvesting on the environment has also been a highly researched area (e.g., Campbell and Doeg, 1989; Payer and Harrison, 1999; Maigret et al., 2014; Earl et al.., 2016). One aspect of timber harvesting that seems to get little attention is the social aspect. There have been several studies that have concentrated on reasoning for forestland ownership and harvesting behaviors of these landowners (e.g., Young and Reichenback, 1987; Dennis, 1989; Bliss, 2008; Bengston, Asah, Butler, 2011), but few have looked into what landowners' experience while selling timber.

Very little research has been conducted on timber-selling satisfaction, but it is an essential feature in timber transactions (Kärhä, 2004). Past studies on family forest 
owner's experiences or satisfaction with timber transactions include e.g., Kärhä, 2004; McGill, Pierskalla, Jennings, Grushecky, \& Lilly, 2006; Moss, 2011. Kärhä (2004). A study from Finland found that landowner experiences with timber transactions were affected by damage to standing trees on their property after the harvest and the amount of logging residue left such as stems and tree tops. McGill et al.. (2006), studied landowner satisfaction with timber harvesting on West Virginia forest stewardship program properties and found three variables that influenced landowner satisfaction. Variables found include: satisfaction with amount of profit earned from the timber sale, if Best Management Practices were discussed with landowner before the timber harvest, and whether a contract had been written specifying requirement's and terms of the timber harvest. Moss (2011), studied the silvicultural and economic impact of professional forestry assistance on timber harvest on family forestlands in West Virginia. Moss (2011), found that landowners who used a consulting forester were more satisfied with price, amount of timber harvested, and more pleased with the overall harvest, compared to those landowners who dealt with industry foresters or loggers. While these studies provide valuable insight into what landowners experience during certain aspects of timber transactions, they do not provide the full picture.

\section{Study Objective}

The timber transaction process is the time from when the landowner decides to sell timber until all harvesting, legal, and financial aspects are completed. This process can be very complex due to the diversity of players and roles they participate in during the timber transaction. Players that can be involved during timber transactions include: 
consulting foresters, procurement foresters, state service foresters, and non-foresters such as loggers (Moss, 2011; Moss \& Heitzman, 2013).

- Consulting foresters - are registered foresters that provide forest management consulting to the landowner and assistance during the timber transaction process for a fee.

- Procurement foresters - are registered foresters that work for a timber buying company.

- State Service forester - is an employee of the West Virginia Division of Forestry (WVDOF) who is a registered forester or technician. They can provide landowner assistance with during timber transaction and also oversee compliance of rules and regulations during the timber harvest.

- Logger - is an individual that provides the service of cutting and removal of timber.

These players have different roles within the timber transaction process and can affect the experience of the landowners. Given the lack of information on family forest owner experiences and the diversity of the roles taken by other parties involved in timber transactions, this research project was designed to broaden the understanding of these complex transactions. The purpose of this study, was to explore the question "what makes for a successful timber transaction?" In order to better understand what family forest owners experience during this full process a qualitative approach was taken. This approach allowed researchers to explore a wide range of family forest owner's experiences with timber transactions, enabling them to better understand what makes for a successful timber transaction and the types of scenarios that can occur.

The goal of this project is to better understand family forest owners' experiences with timber transactions to aid in the development of a future questionnaire designed to capture a wide range of family forest owners' experiences. The results from this study will also allow forestry professionals to better inform and educate future family forest owners how to achieve a successful timber transaction. 


\section{Chapter II: Review of Literature}

\section{Family Forest Owners}

America's forestland provides many goods and services to the public. Some of these goods and services are clean water, forest products, wildlife habitat, open space and recreational opportunities (Stein et al., 2009). There are roughly 751 million acres of forestland in the United States. Family forest owners own 262 million acres or $42 \%$ of the forestland in America (Bliss, 2008; Butler \& Leatherberry, 2004). Forestland is defined as "land at least 10 percent stocked by forest trees of any size. The minimum area for classification of forest land is 1 acre" (Butler, 2008; Smith et al., 2004). These forestlands can be categorized into three primary landownership types (Butler, 2008; Butler, 2012 and Widmann et al. 2012). The first category is comprised of private corporations, nonfamily partnerships, nongovernmental organizations, clubs, and other private nonfamily groups (Widmann, et al. 2012). The second category is comprised of public land ownership which includes state and government owned forests (Widmann, et al. 2012). The third category, and most common landowner type in West Virginia, is family forest owners. This includes, individuals, farmers, small family corporations, and partnerships (Widmann, et al. 2012).

Butler (2008) defines family forest owners as, "families, individuals, trusts, estates, family partnerships, and other unincorporated groups of individuals that own forest land" (p.3). The majority of family forest owners in the United States own less than 10 acres of forest land (Butler, 2008). Family forest owners have diverse and

multidimensional motives for owning land (Bengston, Asah \& Butler, 2011). These 
reasons for owning forestland range from aesthetics, family legacy, privacy, part of home, recreation, and timber production (Butler, 2012). Motives for owning land change over time. Understanding these motives are important to researchers and educators (Butler \& Ma, 2011). A better understanding of family forest owners can help extension foresters develop better educational programs, private consultants to improve their services tailored towards these landowners, and policy analysts to create and implement more effective policies (Bengston et al., 2010).

Research related to private land ownership has been conducted since the 1940's (Barraclough \& Rettie, 1950). The USDA Forest Service institutionalized forest ownership surveys in the 1970's (Kingsley \& Finley, 1975). In 2001, the USDA forest service, Forest Inventory and Analysis (FIA) program instituted the National Woodland Owner Survey (NWOS) (Butler, Leatherberry, \&Williams, 2005). The NWOS is conducted to better understand attitudes and behaviors of family forest owners (Dickinson \& Butler, 2013). The data collected from the survey is used by policy analysts, federal and state agencies, educators, private consultants, nongovernmental organizations, and others to help design and implement policies, programs, and services aimed to promote sustainable forestry practices on private forest ownerships (Dickinson \& Butler, 2013). Family forest owners over the years have been surveyed through mail questionnaires or by personal interviews. These surveys provide valuable information about family forest owners, but provide little insight behind the reasoning behind the statistics. One group of researchers suggest using focus group interviews to gain a deeper understanding of these statistics (Kingsley et al., 1988). Future research of forest owners 
should be open to the advantages of open-ended questions and other sources of qualitative research (Bengston et al., 2010).

\section{Timber Transaction Process}

Selling timber is generally not the primary objective for most family forest ownerships, but when landowners do decide to sell timber this becomes an important objective (Kurtz and Lewis, 1981). Kittredge (2004) states, "many people have home or life insurance, but likewise do not think of it on a daily basis until they need it” (p.16). Similarly, many family forest owners do not think about their timber until they need to sell it. The timber transaction process starts when the landowner decides to sell timber and continues until all harvesting, legal and financial aspects are completed. This process encompasses all the steps landowners will go through when selling timber. At its root, a timber transaction is the process in which a landowner and parties involved have an agreement to exchange timber for payment. This process can be complex as every situation and location is unique and creates their own issues. Three possible key parties involved in the timber transaction process are landowners, foresters, and loggers (McGill, 2006; Keefer et al. 2002). The type of parties and the quality of their services, will influence the landowners' satisfaction. Very little research has been conducted on satisfaction in this process, but it is an essential feature in timber transactions (Kärhä, 2004). Understanding a typical forestland owner's reasoning behind selling timber, and what challenges and successes they experience with timber transactions, will help extension professionals and foresters as they assist and educate forestland owners.

A landowner deciding to sell their timber is typically the first step in a timber transaction. Landowners decide to sell timber for a variety of reasons. The decision may 
be due to financial needs or as a component of fulfilling a written management plan (Bengston, 2011; Butler, 2012; Rickenbach, 2003). Other factors that influence the selling of timber include: age of landowner, number of acres forested, extension activity participation, white collar occupation, years of formal education, and debt-to-income ratio (Silver et al., 2015). Also, market prices and timber owner objectives may influence reasons to sell timber (Butler, 2012; Silver et al., 2015).

After the decision phase the timber transaction process can become very complex. Although there is not a certain set of guidelines landowners have to follow during timber transactions, there are recommendations and precautionary measures landowners can take to help assist and guide them through this process. One recommendation is for landowners to contact and obtain the services of a professional forester. (Moss \& Heitzman, 2013; Stelzer, 2015; Mance et al., 2004). There are three types of professional foresters that can guide landowners during the sale preparation phase. These include procurement foresters, consulting foresters, and state service foresters (Moss, 2011). Procurement foresters are registered professional foresters who work for a timber buying company. Consulting foresters are professional foresters that are hired by the landowner to provide forest management consulting (Moss \& Heitzman, 2013). A state service forester is a registered forester or technician that is employed by the West Virginia Division of Forestry (WVDOF). They also provide forest management consulting and represent the seller (landowner) (Moss, 2011). Depending on the scenario, both types of foresters may be involved during the timber sale. The main difference between consulting/service forester and procurement foresters is that consulting/service foresters work directly with landowners to look out for what is best for the landowner and the 
forest (Mance et al., 2004; Moss, 2011). Procurement foresters will also work with the landowner, but may put the interest of the company over interests of the landowner. It is best to get assistance from a consulting forester before timber sale arrangements are made (Mance et al., 2004).

Professional foresters can provide many answers to landowners' questions and concerns about what steps to take when selling timber (Mance et al., 2004). The job of the forester is to represent the landowner and to advise the landowner in harvesting and sale aspects of the timber transaction process. Services that foresters provide during the preparation of the sale are inventorying timber, marking boundaries, contracts and developing a plan for the harvest (Smallidge, 2016).

The landowner should always have a written contract between themselves and the timber buyer. Contracts can help reduce the possibility of misunderstanding and disagreements during the timber transaction process (Stelzer, 2015). Once again it is advisable to seek assistance with a consulting forester when preparing timber sale contracts (Stelzer, 2015; Mance et al., 2004). After preparations for the timber sale such as harvesting plans and contracts have been completed, the actual removal of standing timber begins.

The harvesting phase is when timber is removed for merchantable use by harvesting crews or loggers. Harvesting crews or loggers provide the service of cutting and removal of timber. The West Virginia Division of Forestry (WVDOF) defines timber harvesting as, "activities directly related to the severing or removal of standing trees from the forest as a raw material for commercial processes or purposes" (2015). 
Once again most recommendations suggest there are a few steps that can be taken to insure landowner satisfaction. First, either the landowner or professional forester should be present the day that the harvest begins. This allows for the opportunity to talk to the timber buyer or logger and clarify points of agreement and ask questions that may not be covered in the contract with the timber buyer or logger (Stelzer, 2015). Foresters will also oversee timber harvesting operations to ensure that, compliance with landowner contract, and completion of the operation is successful. During the harvesting phase in West Virginia, it is required to notify the WVDOF that a harvest is being conducted within three days before or after the start of harvesting operation. Typically, it is the timber license holder that submits the notification which is the person who purchased the timber usually being the procurement forester or logger. The WVDOF will periodically oversee the timbering operation to ensure that the loggers follow all rules and regulations set by the West Virginia Legislature. Loggers in West Virginia are required to be licensed and follow Best Management Practices (BMPs) to control erosion of soil during and after the harvest (McGill et al., 2006). In some cases, landowners may have the resources to conduct a timber harvest without the assistance of a forester and logger. The landowner still has to obtain a timber license through the WVDOF before conducting a timber operation. A timber license exemption can be obtained as long as the stumpage value of the trees does not exceed $\$ 15,528$ (West Virginia Legislature, 2015).

Published literature pertaining to the steps comprising the timber transaction process is limited. Most literature has described recommendations about who to contact and steps to protect landowners during the timber transaction process (Moss \& Heitzman, 2013; Stelzer, 2015; Mance, 2004). To better understand what the timber transaction 
process consists of, the following figures will illustrate two possible scenarios that can take place.

In the commonly used four party scenario there are three phases with several parties involved during each phase. First is the decision stage. As stated before, this is when the landowner makes the decision to sell timber. The next stage is when preparations for the sale are made. In this scenario a professional forester has been hired by the landowner to guide them through this process. In some instances, both a procurement and consulting forester can be involved. The role of the forester in this phase typically includes activities such as inventory of the timber, counseling the landowner on possible alternatives, writing up contracts and making preparation for the timber harvesting phase. At the start of the timber harvesting stage, the WVDOF will need to be notified by the logger and during active operations, both the WVDOF and consulting forester may oversee activities and inspect the logging site. The WVDOF will make sure the loggers are following all required rules and regulations. The professional forester will oversee the logging operation to make sure the contract rules are being followed and harvesting operation is being conducted correctly. 


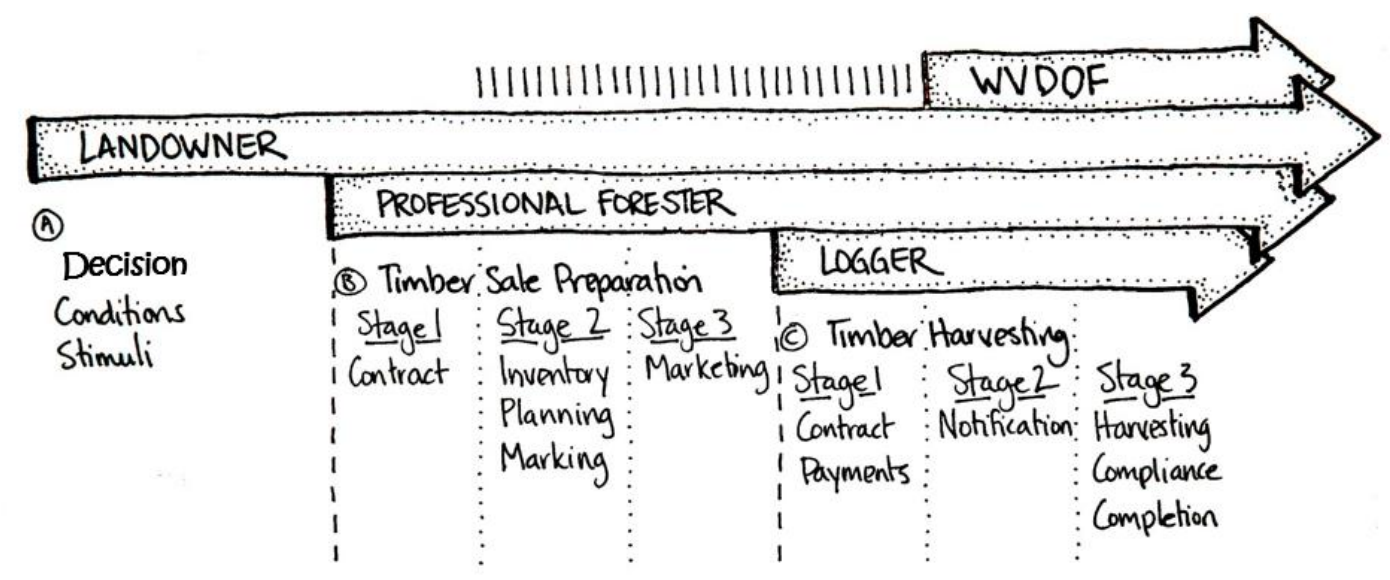

Figure 1. Four Party Scenario Timber Transaction Process. Figure courtesy of D. McGill, West Virginia University Extension Service.

Another common timber transaction scenario removes the forester from the timber transaction process. This is considered to be the three party scenario.

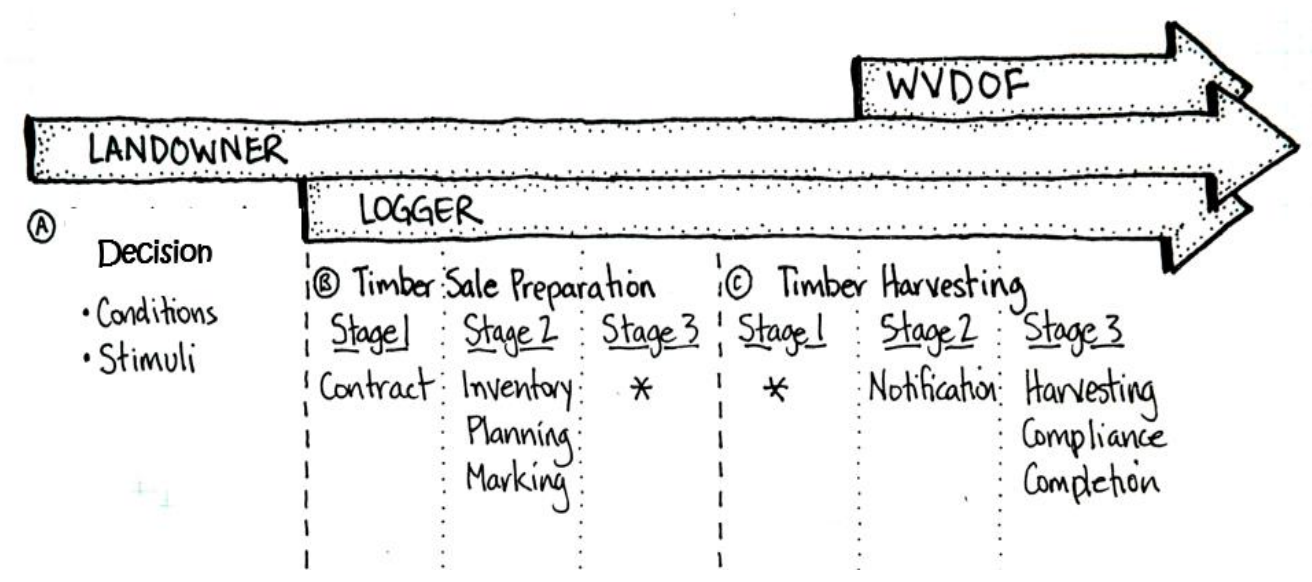

Figure 2. Three Party Scenario Timber Transaction Process. Figure courtesy of D. McGill, West Virginia University Extension Service.

In the three party scenario, all three phases are retained, but the logger will be involved during the sale preparation stage. In some cases the landowner and logger carry out many of the tasks that a forester does. Landowners often receive only a small fraction of what their timber is worth and are unaware of some common logging issues that may occur (Landefeld and Schumacher, 2006). However, landowners are often uninformed 
about timber transactions and the logger may not have the landowners' best interests in mind. Even though this is a common and legal scenario, landowners should always talk to a professional forester before selling timber.

With the number of different timber transaction process scenarios; all with different players and levels of details in each task, it is clear that the process can be complex. Understanding what landowners experience during this period of time is essential in promoting successful experiences. The timber transaction process can also be investigated similarly to other commercial transactions in order to better understand what people experience during this process. By reviewing the literature on customer satisfaction, additional insight and techniques can be identified to capture these landowner's experiences.

\section{Customer Satisfaction}

The forest products industry in West Virginia is a major contributor to the state's economy with an excess of four billion dollars annually, and generating over $\$ 45$ million in taxes to the state (WVDOF, 2010; Childs, 2005). Understanding customer satisfaction is very important to this industry. Customer satisfaction is defined as "the degree to which a customer perceives that an individual, firm or organization has effectively provided a product or service that meets the customer's needs in the context in which the customer is aware of and or using the product or service" (Cengiz, 2010, p.79). Customer satisfaction is a very important component of marketing. The satisfaction of customers is crucial for a number of reasons. For example, if customers are dissatisfied they tend to complain and may give the company a bad review or reputation (Syed \& Conway 2006; 
Oliver, 1987 and Nyer, 1999). A dissatisfied customer can potentially persuade potential customers away from a particular service/service provider. Customer satisfaction and loyalty have a strong relationship (Syed \& Conway 2006; Szymanski \& Henard 2001). Satisfied customers usually tend to use the same service provider and promote that particular company or business.

Measurement of customer satisfaction is one of the main issues concerning business and organizations (Grigoroudis and Siskos, 2009). Customer satisfaction surveys have become a popular way of providing feedback and insight into how companies can improve relations with their customers (Cardis, 2005). Companies measure their performance by asking for customer feedback on a particular product or service. By gathering information on customer satisfaction, a company can determine how a product or service might be improved (Kiess-Moser, 1989).

Depending on the aim of customer service research, methodologies used to gather customer service information may be divided into qualitative and quantitative research (Grigoroudis and Siskos, 2009; Dutka, 1995). The beginning stages of customer satisfaction surveys usually start with qualitative research such as in-depth interviews or focus groups to develop a list of satisfaction attributes (Grigoroudis and Siskos, 2009). In-depth interviews are interactions where the researcher seeks to learn what another person understands about a topic in order to document what the person has experienced (Mears, 2012). Similar to in-depth interviews, focus groups also provide valuable insight to people's experiences and opinions. These are semi-structured discussion groups where four to twelve people explore a specific set of issues (Tong et al., 2007; Liamputtong \& Ezzy, 1999). Once the focus group is completed, the lists of attributes are reduced, and 
the main satisfaction dimensions are determined. A quantitative study can be conducted and the customer satisfaction survey will be created based on the satisfaction dimensions determined from the qualitative study (Grigoroudis and Siskos, 2009). The main goal of the qualitative analysis is to make sure researchers understand enough about the target population in order to design an appropriate questionnaire (Grigoroudis and Siskos, 2009; Hill, 1996).

Figure 3 shows the steps that comprise customer satisfaction research. The figure shows that qualitative research is first used to help develop customer satisfaction dimensions. It is important to first understand the population being studied before creating a comprehensive questionnaire (Grigoroudis and Siskos, 2009).

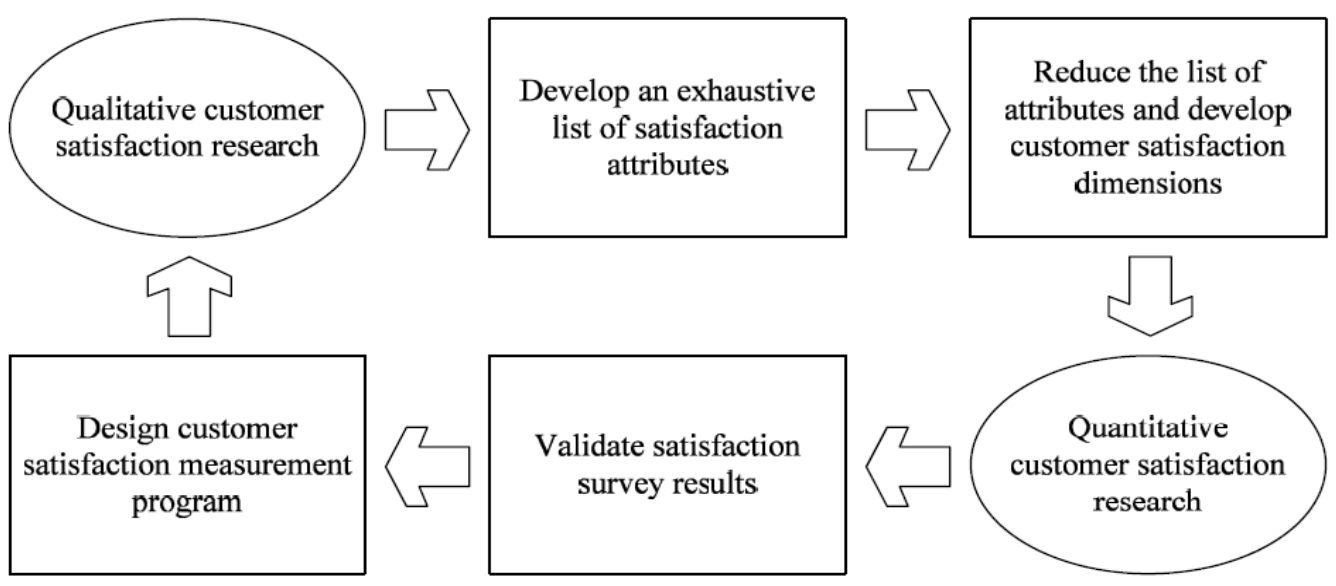

Figure 3. Combining qualitative and quantitative research, (Grigoroudis and Siskos, 2009, p.178).

There have been a few studies from Finland that have examined forest owners' satisfaction with selling timber. In Finland timber procurement organizations and timber contractors have been engaged in quality management systems (Kärhä, 2004). Some procurement organizations have developed surveys that measure the satisfaction level of 
forest owners who have recently conducted timber transactions with them (Kärhä, 2004). One problem that remains is that these companies had the quality of their own performance evaluated and failed to reliably compare their own performance in relation to other companies (Kärhä and Oinas, 1998). It is important to first understand family forest owners experience during timber transactions, to create a reliable instrument that can measure these landowner's experiences.

\section{Focus Group Interviewing}

Qualitative research is defined as gathering non-numeric data to study in order to gain a better understanding of the population of interest (Ary et al., 2014). Focus groups are one common qualitative research method. Focus groups are a form of group interview that allows researchers to capture communication between research participants (Kitzinger, 1995). The main goal of focus groups is to gather information in order to answer research questions. Focus groups are used to gather information on different viewpoints, experiences, beliefs, and to understand the reasons of participants' views (Gill et al., 2008). The theory behind focus group methodology is that group processes can help researchers explore and clarify people's views in ways that would be less accessible in a one-on-one interview (Kitzinger, 1995). Focus groups can help improve the morale among participants and demonstrate that an organization is listening to the users of its services (Powell, 1996).

The use of focus groups date back to the 1940's where a group of researchers at the Bureau of Applied Social Research at Columbia University were studying radio media and the effects on listeners (Kamberelis \& Dimitriadis, 2013). Focus groups are 
used today in numerous consumer industries in order to gain insight on the consumers' experience. This helps researchers to better understand the population being studied, so questionnaires can be formulated to capture participants' experiences (Gill et al., 2008).

Conducting a focus group generally consists of a moderator and five to ten participants. The meeting typically takes between one to two hours to complete. It is recommended that the participants in the groups have similar backgrounds or experiences in order to capitalize on these shared experiences (Kitzinger, 1995 and Powell, 1996). The researcher should schedule the meeting in a neutral zone meaning that the area should not bias participant's views or responses. The atmosphere of the meeting should be relaxed with refreshments provided. Comfortable settings and having participants sit in a circle also help to create a relaxing environment for the participants of the focus group (Kitzinger, 1995). In order to gain a better understanding of the population being studied, the moderator of the focus group asks participants a list of questions, prepared prior to the meeting. The moderator should be relaxed, a good listener and nonjudgmental. It is advisable that the moderator remain after the session in case any participant wants to talk one on one (Powell, 1996). 


\section{Chapter III: Methodology}

The purpose of this study was to understand what West Virginia family forest owners experience during the timber transaction process and what they perceive as a successful timber transaction. A focus group was conducted to gain a deeper understanding of what family forest owners experience and view as a successful timber transaction. This method of data collection was determined to be the most appropriate to use in this study for several reasons. First, it allowed researchers to capture a wide range of responses about the phenomenon being studied (Dooley, 2007). For this study the phenomenon is family forest owners' experience with timber transactions. Secondly, observations observed during the focus group helped researchers grasp the motives, beliefs, concerns and interest of participants. Observations help provide a framework of context and guide the findings based upon understood knowledge (Lincoln \& Guba, 1985). Focus groups are used to collect qualitative data where there may only be one chance in capturing the data (Dooley, 2007). In the case of this study, there was only one chance to capture this data. Two research questions that guided this study were:

1. What do landowners view as a successful timber transaction?

2. What factors influence success?

This study was conducted in three phases: (1) the recruitment phase, (2) the data collection phase, and (3) the analysis phase. The use of focus group interviewing was used to gather experiences from West Virginia family forest owners who have been involved in the timber transaction process. This allowed the research team to gain a more 
thorough understanding of what family forest owners experience during this complex transaction period.

\section{Design of the Study Phase I: Recruiting Family Forest Owners}

After the approval from the West Virginia University Institutional Review Board on November $6^{\text {th }} 2016$, the first phase of the project was completed. The Institutional Review Board (IRB) assures that the appropriate steps are taken to protect the rights and welfare of humans participating in a research study. Since this study examined family forest owners' experiences and would not cause any harm to the participants, our research team was granted an exemption from the IRB. All participants' names and responses were kept confidential. Code names were given to each participant to protect their identity.

The first phase of this project consisted of recruiting family forest owners who had recently conducted a timber harvest in West Virginia. Purposive sampling was used to recruit participants. "Purposive sampling is a nonprobability sampling technique in which subjects are judged to be representatives of the population being studied" (Ary et al., 2013, p. 681). For this study only family forest owners who have experienced the timber transaction process were chosen to participate in the study. Maximum variation sampling was used to select participants. "Maximum variation sampling includes units that will maximize differences on specific characteristics" (Ary et al., 2013, p. 678). This study was designed to bring out the wide range of viewpoints on family forest owners experiences during the timber transaction process. 
Table 1. Participants and Attributes Chosen for the Study. $(n=8)$

\begin{tabular}{|c|c|c|c|c|c|}
\hline Identification & $\begin{array}{c}\text { Year of } \\
\text { Sale }\end{array}$ & $\begin{array}{l}\text { Resident of } \\
\text { Property }\end{array}$ & $\begin{array}{l}\text { Satisfaction } \\
\text { Level }\end{array}$ & $\begin{array}{l}\text { Forester } \\
\text { Involved }\end{array}$ & Reason for Sale \\
\hline Jon & 2016 & Yes & Moderately & Yes & Part of Registered Forest Plan \\
\hline James & 2016 & No & Moderately & No & Salvage Cut \\
\hline Philip & 2016 & No & Moderately & No & Income \\
\hline Ann & N/A & Yes & Slightly & Yes & Conditions of Fathers Will \\
\hline Tim & 2012 & Yes & Very & Yes & Part of Timber MGT Program \\
\hline Steve & 2015 & No & Moderately & No & $\begin{array}{c}\text { Remove Dead and Damaged } \\
\text { Trees }\end{array}$ \\
\hline Amy & 2013 & No & Extremely & Yes & Management Plan \\
\hline Aaron & 2012 & No & Not at all & No & Income \\
\hline
\end{tabular}

*Note. Scale of Satisfaction ranged from Not at all, Slightly, Moderately, Very, and Extremely.

Starting in the fall of 2015, family forest owners' names were obtained using the Logging Operation Notification Inspection and Enforcement (LONIE) database and the WVDOF notification archives. The LONIE database contains all the timber notification forms submitted to the West Virginia Division of Forestry (WVDOF). Since the WVDOF notification from does not specify the landowner type, certain variables were used to distinguish family forest owners from non-family forest owners. All landowners with key descriptions such as, "corporation, club, organization, governmental, land group, and partnership" were considered non-family forest owners. Once these non-family forest owners were filtered out, all the remaining timber harvests were considered to be those of family forest owners. 
Due to the large number of family forest timber harvests $(23,423)$ since January 2001, several other factors were used to filter this population even further. With WVDOF notifications dating back to 2001, it was decided to exclude all family forest owners from Jan 2001-Dec 2011. The main reason for excluding these landowners was due to the large time gap between their experience and the study. After these family forest owners were filtered out, 8,154 family forest owners remained from Jan 2012-Sept 2016. Due to the geographical location of the study which took place in Morgantown, West Virginia, five counties surrounding Morgantown were chosen. These counties included Marion, Monongalia, Preston, Taylor, and Wetzel. Within these counties 551 timber harvests had occurred on family forestland between Jan 2012-Sept 2016. From this list, 400 randomlyselected family forest owners were mailed a recruitment cover-letter describing the study and a pre-addressed postcard.

On November $28^{\text {th }} 2016,400$ cover-letters and pre-addressed postcards were mailed to family forest owners. The cover-letter described the purpose of the study and the reasoning for the pre-addressed postcard. The cover letter explained why family forest owners' timber transaction experiences were important to researchers. The cover letter also explained that the purpose of the study was to gain a deeper understanding of landowner's experience's with different people, equipment and logistics during the full timber transaction process. Details about the location of the study were provided. Participants were offered a $\$ 50$ incentive if selected for the study. Participants were given until December 9, 2016 to return the postcard. The postcard contained five questions designed to choose family forest owners who had different timber transaction experiences and factors that influenced those experiences. The last question asked if they were willing 
to participate in the study. They were also asked to provide contact information and choose from three dates they would be available to meet for a focus group. Giving the participants three dates to choose from allowed us to narrow down one date for the focus group. The purpose of these questions were to choose participants with different experiences to capture diverse views so all influencing aspects of the timber transaction process would be brought out in the study. After participants were chosen, a follow-up phone call was made and a reminder letter was mailed to participants. Please see Appendices for initial cover-letter, postcard, and reminder letter.

\section{Phase II: Data Collection Focus Group Interviewing}

On January 12, 2017 the West Virginia family forest owner focus group was conducted. This focus group consisted of nine participants, who represented eight different family owned forest lands. In addition to the nine participants, four members of the research team were present. The research team consisted of a moderator, two note takers, and one observer. The moderator was given a semi-structured guide that contained a list of question prior to the focus group. These questions were designed to bring out the participants' experiences during their respective timber transactions. In addition to notes being recorded, audio recorders were used to capture the questions and responses. The focus group was held in a conference room of a local hotel where the setting was comfortable and relaxed. Refreshments were provided to the participants in order to maintain a pleasant atmosphere. The focus group lasted around two hours and thirty minutes. At this point, researchers felt that all designed questions had been addressed and data saturation had been reached. Participants were given a demographic survey and a $\$ 50$ VISA gift card for their participation at the end of the focus group. 
Once the focus group interview was completed, the research team exchanged notes and thoughts about what was observed during the focus group through peer debriefing. This helped establish credibility through data triangulation (Tracy, 2010). The audio recordings were transcribed using an online service. After the audio recordings were transcribed the process of analyzing the data began.

\section{Phase III: Coding}

The constant comparative method was used to analyze the data. This method compares one segment of data with another to find similarities and differences (Merriam, 2009). Categories and patterns are identified in relation to each other in the development of a grounded theory (Merriam, 2009 and Glaser \& Strauss, 1999). For this study, the constant comparative method allowed researchers to analyze the data, so that an overall theory of what makes for a successful timber transaction could be determined.

The constant comparative method was conducted in three stages. During the first stage open coding was used to analyze the data line by line (Onwuegbuzie et al., 2009; Dooley, 2007 and Strauss \& Corbin, 1998). Open coding "is the process of breaking down and categorizing qualitative data into manageable segments" (Ary et al., 2013, p. 680). The use of notecards were used to display actions and events aiding in categorizing data. There were provisional codes given to comments made by family forest owners. After going through the entire transcript, codes that had similarities were grouped together. The process of grouping open codes is called axial coding. Axial coding, "is the process of making connections between and across categories" (Ary et al. 2013, p. 682). The use of axial coding develops sub-categories around the core categories. Ary et al., 
(2013) describes this as being like a wheel with spokes, all the spokes extend from the wheel, but all are related to the core category. The third and final stage was selective coding. Selective coding, "is the process of systematically reviewing qualitative data to look for a specific category or theme" (Ary et al., 2013 p. 682). This final stage of coding shows how categories are related. Once these three stages were complete conclusion and implications were made.

\section{Trustworthiness of Study}

Verifying qualitative methods has received much discussion in the field of qualitative research. This is mainly due to the small sample size of the phenomenon being studied (Dooley, 2007). Small sample sizes are common in qualitative studies, mainly due to the fact that there is a point of diminishing return to a qualitative sample (Mason, 2010; Ritchie, Lewis, \& Elam, 2003). Meaning, as the study continues on, more data does not always yield new information. Because frequencies are rarely important in qualitative research, one occurrence of the data is potentially as useful as many in understanding a topic (Mason, 2010; Ritchie, Lewis, \& Elam, 2003). Also, due to the fact that qualitative research can very time consuming, analyzing a large sample is labor intensive and often impractical (Mason, 2010).

Several steps were taken in this study to verify the findings. Trustworthiness criteria by Lincoln \& Guba (1985), were followed to establish credibility (internal validity), transferability (external validity), dependability (reliability), and conformability (objectivity). These criteria will provide trustworthiness for this study. 
Credibility is verifying the truthfulness of the findings (Ary et al., 2013).

Credibility was achieved using several techniques that Lincoln \& Guba, (1985) suggest will help produce credibility in the findings. The first technique was triangulation which is using multiple observers and data collection techniques (Ary, 2013). During the focus group interview there were a total of four observers. Two researchers were taking notes on participant's interactions and responses during the focus group. One researcher was observing the focus group and the moderator was writing down notes about the focus group. In addition to the researcher's observations and notes, audio recorders were used to capture the responses of the participants. Peer debriefing was conducted directly after the focus group and during the analysis of data, to check everyone's work and to help avoid any research biases. Triangulation was completed with members of the research team comparing their findings from the focus group notes. Peer debriefing and triangulation aided in the credibility and results of this study.

The use of purposive sampling helped to establish transferability. Dooley (2007) states, "transferability is grounded in adequate description, thus it is imperative that the data be provided by those who know it best" (p. 39). Although this research team used purposive sampling, this study has low transferability due to the fact that only five counties were represented in this study. The results from this project can be used to describe what family forest owner's from the counties chosen for this study view as a successful timber transaction.

The reliability of this study is also important so researchers can repeat or replicate similar studies. In qualitative research this is called dependability. Dependability is defined as, "the extent to which the same general results would occur with different sets 
of people or different settings and time periods" (Ary et al., 2013 p. 675). Dependability was accomplished by providing a detailed audit trail of the methodology. The methodology section outlines each step taken regarding who, how, and when this project was conducted.

In similar fashion to establishing dependability, conformability can be obtained. Conformability is how other researchers investigating the same situation, can use findings from this study to corroborate their own (Ary et al., 2013). To establish conformability an audit trail of data was documented. The data audit trail can be traced back to the original source. This encompasses field notes and audio transcription of the focus group, to the coding and analysis of the data phase.

\section{Use of Findings}

The findings will allow the forestry community to better understand the timber transaction process. This will allow researchers make generalizations about what landowners view as a successful timber transaction experience. In turn, outreach and educational programs can be designed to help inform individuals involved in the timber transaction process how to achieve successful and satisfactory experiences. This project is also designed to inform the development of a landowner timber harvesting satisfaction survey. Conducting focus groups as an initial phase in questionnaire development will help guide effective question development that captures family forest owners experience and satisfaction. Kingsley et al., (1988) states, "Focus groups provide a device to guide the design of mail questionnaires" (p. 198). 


\section{Chapter IV: Results}

The purpose of this study was to explore what family forest owners experience during the timber transaction process. The objective of the focus group was to gain a deeper understanding of these landowners and what they experienced and view as a successful timber transaction. The overall goal of this project is to develop themes that emerged from the data to assist with the creation of a future questionnaire. The questionnaire will be designed to measure a broader set of landowners experiences based off what was learned from the family forest owner focus group.

\section{Postcard Response and Cooperation Rates}

Initially, 400 recruitment postcards were mailed to West Virginia family forest owners from Marion, Monongalia, Preston, Taylor, and Wetzel counties. All of these family forest owners had recently completed a timber transaction. Out of 400 postcards, $69(17 \%)$ were mailed back. From the 69 postcards mailed back, 22 (32\%) said they would be willing to participate in the study. There were three dates that family forest owners had to choose from to participate in the focus group. These dates were January 12,13 , or 14 . Out of these three dates, January 12 was the most selected date. Fourteen (64\%) of the twenty-two family forest owners said they could participate on this date. Using the selection process detailed in the methods section, eight different family forest owners were selected to participate in the study. 


\section{Profile of Participants}

Table 2. Participants Demographic Information $(n=8)$

\begin{tabular}{llllll}
\hline Identification & Gender & Profession & $\begin{array}{l}\text { Year of } \\
\text { Sale }\end{array}$ & $\begin{array}{l}\text { Resident of } \\
\text { Property }\end{array}$ & $\begin{array}{l}\text { Use of a } \\
\text { forester }\end{array}$ \\
\hline Jon & M & Retired & 2016 & Yes & Yes \\
James & M & Business Owner & 2016 & No & No \\
Philip & M & Retired & 2016 & No & No \\
Ann and Chris* & F & Retired & N/A & Yes & No \\
Tim & M & Pilot & 2012 & Yes & Yes \\
Steve & M & Landlord & 2015 & No & No \\
Amy & F & Free Lance Writer & 2013 & No & Yes \\
Aaron & M & Retired & 2012 & No & No \\
\hline
\end{tabular}

* The $9^{\text {th }}$ participant is the husband to Ann. His identification name is Chris. Their responses will be paired together since they shared the same experience.

$\underline{\text { Jon (pseudonym) }}$

Jon is retired and bought 38 acres of land about three years ago. He decided this is where he was going to live. He is also part of the managed forest program where he was assigned a consulting forester that made a forest management plan for him. Jon's property was timbered in 2016 where he stated on the postcard that he was moderately satisfied with selling timber.

\section{$\underline{\text { James (pseudonym) }}$}

James is a local business owner that owns several hundred acres in West Virginia. His most recent timber sell was in 2016 due to trees that had been cut by a utility company on right-of-ways that run through his property. He was moderately satisfied with the overall process. 


\section{$\underline{\text { Philip (pseudonym) }}$}

Philip is a local landowner that is retired and had his property timbered in 2016. His reasoning for selling timber was for income and was moderately satisfied.

\section{$\underline{\text { Ann and Chris (pseudonym) }}$}

Ann inherited 128 acres of land, where she and her husband Chris are retired and live. One condition of her father's will was that the property had to be timbered and the money split between heirs. Ann stated, "We are the examples of doing everything wrong". This couple was slightly satisfied with their overall experience.

\section{$\underline{\text { Tim (pseudonym) }}$}

Tim is a local landowner and helicopter pilot. He participates in the timber management program, where his most recent timber sell was in 2012. Tim was very satisfied with his experience.

\section{$\underline{\text { Steve (pseudonym) }}$}

Steve is retired but still has several rental properties that he maintains. He also owns several tracts of timber in the state. His most recent timber harvest was in 2015, where he said the property had a lot of dead or damaged trees. Steve did not provide as much information as the other participants during the focus group. 


\section{$\underline{\text { Rachel (pseudonym) }}$}

Rachel is a freelance writer and is also retired. Ms. Rachel has a management plan and talked to a consulting forest before selling her timber. Her property was timbered in 2013 where she said she was extremely satisfied.

$\underline{\text { Aaron (pseudonym) }}$

Aaron is retired and owns his property for recreational use. He decided he needed some extra income and had his property timbered in 2012. He was not at all satisfied with his experience.

The participants in this study included nine individuals representing eight family forest owned properties (Table 2).

\section{Focus Group Interviewing Results}

Within the context of the transcripts five main themes, comprised of a list of attributes, were found to affect family forest owners' experience during their timber transactions. These five themes that emerged from the data were: Decision for the Sale, Peoples' Involvement in the Sale, Information \& Education about Selling Timber, Trust of People and Legal Aspect in Selling Timber (Table 3). 
Table 3. Five main themes and list of attributes that influence family forest owners' timber transaction experience.

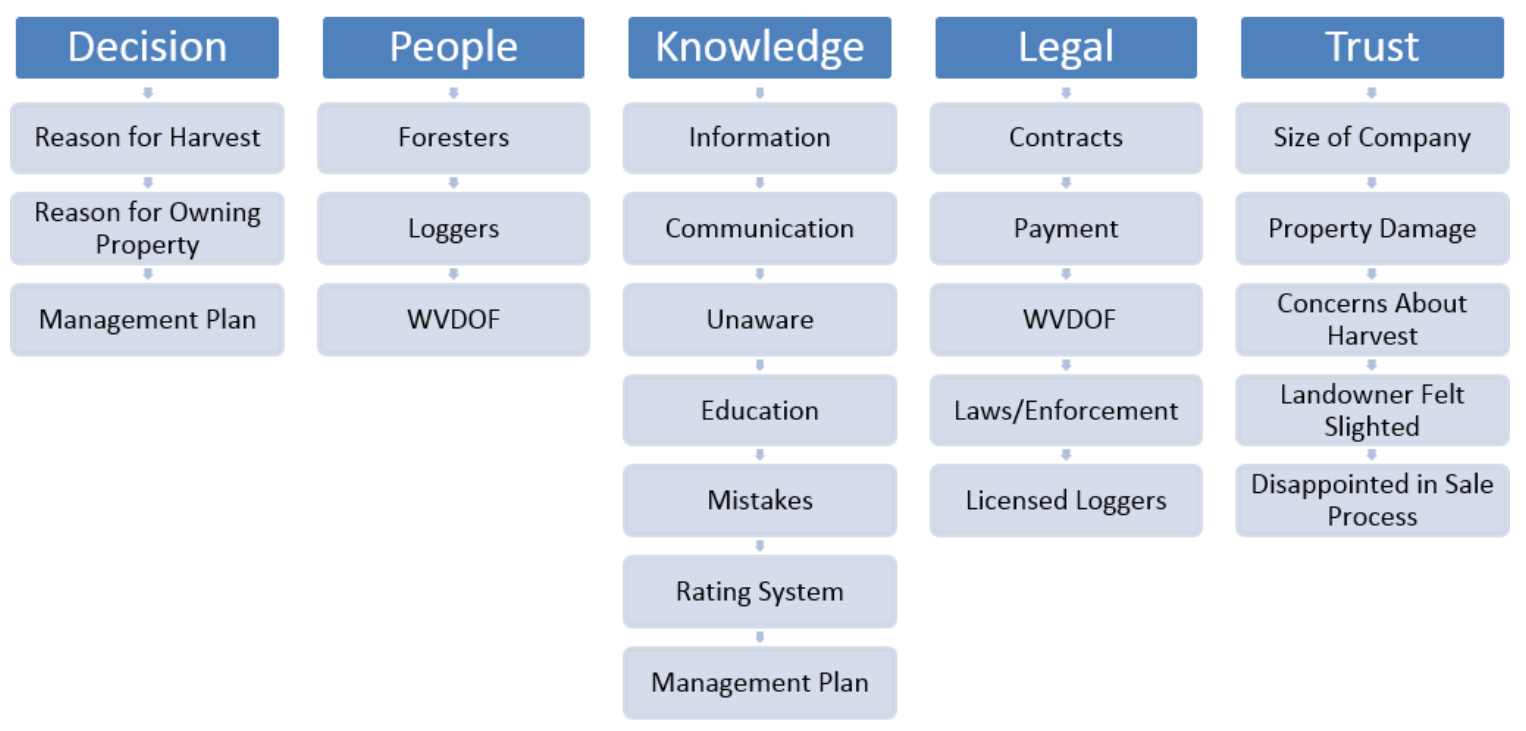

From the five main themes there are a list of attributes that were found to have an effect on family forest owners' experiences. These attributes were found to have an influence on landowners' experience. Attributes that are similar were grouped together making up the five main themes found throughout the transcripts. These attributes are important to the researcher because they show what factors influence landowners experience in each theme.

\section{Findings by Themes}

\section{Decision}

The first question that was asked during the focus group was, why did you sell timber? Two characteristics that greatly influenced landowners' decision for selling were reasoning for property ownership and reasoning for timber sale. 


\section{Property Ownership}

From what was observed, the reasoning for property ownership played an important role in landowner's decision to sell timber. Some landowners called this property their home (Jon, Ann, Tim), while others own their property for financial investment (James, Philip, Steve). A couple of participants indicated they owned the property for recreation (Aaron) or their property had been inherited (Rachel, Ann). The next characteristic that influenced landowners' decision for selling timber was their reasoning for selling timber. This characteristic will show how property ownership played a role in landowners overall decision to sell timber.

\section{Reason for Selling Timber}

Landowners had different reasons for selling timber. These reasons included: clearing property for a house (Jon), he stated, "As a function of moving a double wide onto our property, one thing we needed to do was get it logged off'. Other landowners who said they owned their property for financial investments, indicated they needed to salvage timber that had been cut by oil and gas companies or due to insect damage and disease (James, Steve). Another participant who is a resident of the property, said "one of the conditions of her fathers will was to have the property timbered" (Ann). One landowner, Tim, who also lives on the property says, "We treat timber as a crop, harvesting 100 acre block every seven to ten years". Rachel, who had inherited her property states, "I knew that you were supposed to pay attention to your timber. You didn't want it all just falling down". Her main reasoning for selling was that she wanted to keep the land in good shape. One other participant owned the property for recreational 
use (Aaron). He stated, "I never thought about cutting a tree, but at some point you need to cut those tress, otherwise you lose them".

Once landowners started discussing about their decision to sell timber, they quickly began to describe their whole experience from start to finish. The first main theme to develop that influenced landowner experience was Decision. This was mainly due to the nature of the first question being asked. Four more main themes emerged once landowners started telling their stories. These include Knowledge, People, Trust, and Legal.

\section{Knowledge}

The amount of information and education prior to selling timber was a big factor in landowners' overall experience. Some of the participants had searched and found information before selling timber (Jon, Tim, Philip, Amy, James), while others were unaware about where to go for help (Ann, Aaron). Most participants agreed that information about selling timber was difficult to find. Some attributes that developed within the theme of Knowledge were, source of information, the idea of a rating system, and forest management programs.

\section{Source of Information}

Multiple participants indicated that information about selling timber was hard to obtain. "It took a while to actually find that Managed Forest program" (Jon). One participant indicated the main thing is to go onto the Division of Forestry website but, the average person does not have an idea where to go (James). Several participants suggested 
that there should be some sort of advertisement designed to guide landowners towards information about selling timber (Jon, James, Aaron, Ann). The majority of participants agreed information is the most important thing to everyone.

\section{Rating System}

One topic that clearly interested the group was the idea of a rating system for foresters and loggers. One participant stated "that there's not enough information out there that I can use to actually go through and find the good people, you really need ratings, but there's no rating system that I know of' (James). Another participant indicated it would be beneficial to have a referral system, where a landowner could post their experiences and satisfaction about the companies involved during their timber sale (Aaron).

\section{Forest Management Plans}

Several participants indicated that they were part of a forest management program (Jon, Philip, Tim, Rachel). Forest management played a role in the overall knowledge landowners had about selling timber. Jon states, "My forester put together a management plan that told me everything I needed to do". Rachel had a management plan that outlined her property in seven sections and recommended different harvests for each section. Tim, participates in the forest stewardship program where they looked at his property and made recommendations about what he should do with his timber. The participants that had some type of forest management plan possessed an overall better understanding about selling timber. This is because they had a set of guidelines to follow about how the timber sale should be conducted. 
The amount of information landowners gained before selling timber had a big influence on their knowledge of who to contact about harvesting and selling timber. This brings up another theme that came out during the focus group which is People involved during the sale.

\section{People}

Peoples' involvement during the timber transaction were found to greatly influence landowners' experience. Three out of the four participants that had forest management plans indicated that they were assigned a consulting forester through the WVDOF. The consulting forester then contacted loggers or a procurement forester to purchase the timber (Jon, Rachel, Tim). (Philip) says, "I turn everything totally over to the company that writes the check". Three of the landowners said they contacted a logger about selling their timber (Ann, Steve, Aaron). One participant has an educational background in forestry and he contacted a timber buying company who employees procurement foresters (Philip). This brings up a topic within the theme of People and that is how landowners felt these people influenced their experience.

\section{How People Influenced Landowners Experiences}

Two participants that did not have a forester involved during the sale indicated that this led to their overall negative experience (Ann, Aaron). They also mentioned they did not know to contact a forester about selling timber. (Ann) states, "The first thing we didn't do was go to a forester". She and her husband contacted a small logging company. They felt the loggers did a lot of damage and destruction to their property. Ann says, "So a lot of it's our fault, we should have contacted a forester". One participant said, her 
"forester was marvelous". Her forester listened to her desires and supervised the timbering operation from start to finish. She said, "Her experience was just wonderful" (Rachel). Another participant said, "You need to get the right forester. A forester that has the same vision as yours. We've been blessed with a friend of the family who is a consulting forester. Our experience has been overall positive" (Tim).

Within the theme of People the issue of trust begins to emerge. Trust was either found to be positive or negative in how landowners viewed different people involved during their timber sale. Since the issue of trust was found throughout the transcripts from the focus group, it was decided that Trust was also a major theme found to influence landowners' experiences.

\section{Trust}

Within the theme of Trust a couple of characteristics developed. These include: size of the company and landowners trust in people with the overall sale process.

\section{Size of Company}

One interesting factor that developed in the theme of Trust was the size of the company. When landowners referred to a company they were talking about the logging company. Several landowners felt that smaller companies were less trusting than larger firms (Chris, Tim, Aaron). (Chris) indicated they contacted a "small outfit" that we stumbled across, "we thought he was honest, and he probably thinks he is". (Tim) states, "The size of the company does absolutely makes a difference with the professionalism". (Aaron) had a friend whose nephew was a logger which he hired to timber his property. 
He says, "A small logger, four man crew, all the tell-tale signs of things you shouldn't be doing, which I didn't know at the time". Another participant (Jon) had a small independent logger timber his property mainly due to limited access to his property. He said, "His forester got ahold of a small independent logger" and his forester stated, "as far as small independent loggers go, he is more honest than the rest". It is interesting to note that people who had smaller companies timber their property, thought the company was less honest than the larger companies.

\section{Landowners Trust in People}

Landowners' trust they put in people during the timber transaction process seemed to influence their overall experience. One landowner who had a consulting forester was pleased with him, but he had trust issues with the loggers (Jon). When the logger first started the landowner noticed a pile of logs were gone without him knowing. He says, "I told the logger you won't haul a load of logs unless I'm here and I was there every day". He then goes on to say, "I watched exactly what they were doing, I paid attention". Jon then says, "I'm not a very trusting person". Another participant said, "We're here to just tell people make sure you go to a forester. Because you cannot trust some of these people" referring to loggers (Chris). (Ann) feels they should have contacted a forester and feels they got ripped off "Big Time". One landowner indicated he only received a fraction on the money he was promised. He said, "Supervision is an extremely important thing. Either you be there, or have a forester there" (Aaron).

The transcripts from the focus group show that landowners felt that you should seek assistance from a forester and put your trust in them to guide landowners through 
the timber transaction process. Another theme that emerged during the focus group was Legal issues. Several legal issues arose, especially with the landowners (Chris, Ann, and Aaron).

\section{Legal}

Several topics within the theme of Legal came out during the focus group. These include the West Virginia Division of Forestry's (WVDOF) enforcement of laws and contract issues that occurred between the landowner and people involved in the timber transaction.

\section{West Virginia Division of Forestry}

One participant indicated that the WVDOF should do more to protect landowners and more job monitoring. He indicated that he felt let down by the WVDOF. He had filed a complaint with the WVDOF about the loggers stealing timber from his property. He

states, "Instead of the WVDOF coming and listening about my complaint, they were only interested with the Division of Highways guy that was going to sue me for damage to the road" (Aaron). He felt there should be recourse against the loggers that stole his timber but thought the state did not care about what was going on. There was some disagreement among landowners about how (Aaron) felt. Several others agreed that if he filed a complaint that the WVDOF would have taken recourse against these people. They also implied that there's just not enough state foresters in the state to enforce and monitor all the laws (Philip, Steve). 


\section{Contracts}

Seven out of the eight landowners indicated they had a contract agreement between loggers and foresters. Four out of the eight landowners seemed to have no issues in dealing with contracts between them and parties included in the contract (James, Philip, Tim, Rachel). One participant had considered going for a breach of contract for logs that were stolen off his property, but felt it wasn't worth the legal battle (Jon). He was able to resolve the issue by being on the property every day the loggers were working.

Two landowners that had the greatest issues with contracts were (Aaron, Ann and Chris). The main issue that (Chris and Ann) had was that their original logger who signed the contract ended up selling the contract to another logger. Which they both agreed upon that the original logger could sell the contract. (Ann) says, we could have probably got out of the contract at that point, but we were rookies". They realized they were getting ripped off. Chris says, "It was a nightmare from start to finish, but it's like what are we going to do? We signed the contract" The reason they could not do anything is because they agreed up front on the dollar amount before the timber harvest.

(Aaron) had several issues with his contract. He says, "I thought I was doing some of the contract things that a person would do to protect themselves". He and the logger agreed to split the money 50/50. In the end, the loggers did not give him his share of the profit. He says, “The invoice and number of logs hauled out didn't quite match". He felt very disappointed in the timber sale and the people involved. 
From what was observed, the landowners who had a forester had significantly less issues with contracts than those without. (Tim) states, "Don't allow yourself to be put in a place where you're a contract manager'. His forester oversees all of that. This comes back to the theme of Knowledge. Landowners who knew to contact a professional forester first had an overall positive experience with contracts and the people who were in agreement with the contracts.

\section{Summary of Finding}

Throughout the focus group, it became clear that knowledge had the most influential impact on landowners' experience during the timber transaction process. Landowners who were aware about who to contact and steps that were involved in the timber transaction process seemed to have an overall positive experience. Most of the participants did agree that information about selling timber was not easy to find. Landowners who did receive information about selling timber, said they really had to search for assistance and information about timber harvesting. The majority of landowners felt that more should be done to inform landowners about how and who to contact prior to selling timber.

One attribute that developed in the Knowledge category was the idea of a rating system for foresters and loggers. The majority of landowners felt that there should be information provided that shows customer reviews of foresters' and loggers' previous jobs. This idea of a rating system brought out that there are issues of trust that exist between landowners and individuals involved in timber transactions. 
The themes Trust and Legal seemed to have a very close relationship. The majority of landowners had contracts between loggers and timber buyers. They put their trust in the contract and individuals that agreed on the contract. In some cases everything went well, but in other cases landowners felt there was a breach of contract and timber was being stolen off their property. Breach of contract means that some component of the contract was broken, leading landowners to believe that they were being cheated or needed to take legal action against these people.

Trust can either have a positive or negative influence on family forest owners' experience. Nearly everyone had mostly positive experiences with foresters. It was the loggers that they had trust and legal issues with. This is not to say that all loggers treat landowners unfairly, but landowners should take precautionary measures when selling timber. These findings relate back to the category of Knowledge. Landowners who were unaware of who to contact and how to manage the timbering operation had an overall negative experience. Although there were a few landowners who hired foresters, and still had some issues, these issues were resolved through their forester or by the landowner's awareness of what was happening.

The next figure shows how all these categories are related and the effect they have on landowners' experience. It was found through the constant comparative method that Knowledge had the greatest impact on family forest owners' overall experience and throughout the other four categories: Decision, People, Trust and Legal. 


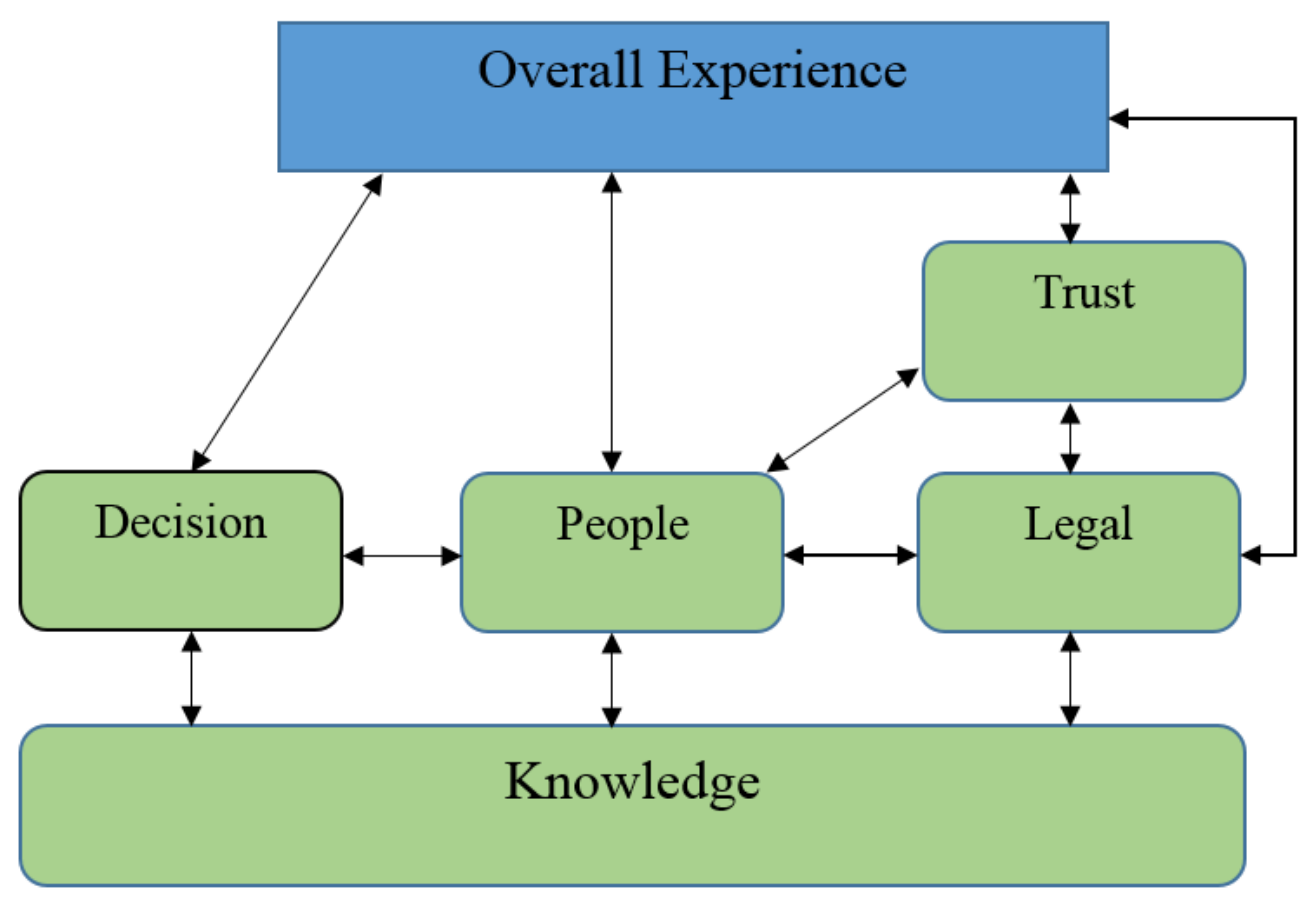

Figure 4. Relationship of categories and their influence on landowners' experience

Figure 4 illustrates how the five main themes are connected and suggests how they influence landowners' experiences during timber transactions. This figure is a conceptual model developed by the researcher grounded in the data collected for this study. Knowledge was found to be the foundational theme that influenced landowners' experiences with timber transactions. Landowners' overall knowledge about timber transactions played a role in their decision to sell timber, to the people they contacted about selling timber, and legal aspects such as contracts and awareness of best management practices. The overall knowledge of the landowner regarding timber transactions affected their experiences during the transaction. Through the themes of People and Legal the theme of Trust emerged. Landowners put their trust in the people involved in the timber transaction and legal aspects such as contracts to insure they were receiving a fair and honest job. In some cases, landowners' felt cheated by the people 
involved and that contract agreements were broken, which affecting landowners' overall experience with their timber transaction.

This figure also assists with understanding the timber transaction process. Once participants started talking about why they decided to sell timber, they then began to talk about people involved during the timber transaction process. All landowners made certain arrangements with people before the actual timber harvest began. Several themes emerged from this area of the focus group. These include "People" landowners contacted, whether it was a forester, logger or timber buyer. They all knew they needed to contact someone about selling their timber. The amount of information and education landowners had received on timber harvesting influenced who was involved during the preparation of the sale. The majority of landowners who were informed about selling timber contacted a professional forester first and put their trust in the forester to guide them through the process. The landowners who were unaware about the process of selling timber contacted a logger about selling timber, and most had negative experiences. This stage of the focus group brought out that Knowledge prior to selling timber is a crucial factor in landowners' experience, because informed landowners knew who to contact and what steps to take. Along with the themes of People and Knowledge, Trust and Legal Aspect also emerged from the timber sale preparation phase. People who were involved during the timber sale preparation phase, were trusted by the landowners to uphold the contracts that were agreed upon and to ensure them they were receiving an honest job.

When landowners started talking about the timber harvesting phase, some components, such as peoples' involvement and legal aspects, were quickly discussed in a negative context. The landowners that hired a forester had an overall positive experience 
during this time period. While some landowners had a few minor issues, these issues were quickly resolved. The two participants that had the most negative experiences during this phase did not use a forester. They both said they did not know to contact a forester about selling timber. Their stories are similar in nature where they felt very disappointed in the result of their timber harvest. Everyone agreed that information and education is the key to having a successful timber transaction. 


\section{CHAPTER V: CONCLUSION}

\section{Summary of Study}

This initial study was designed to explore what constitutes a successful timber transaction from the view point of the landowner. The successes and challenges we learned from the landowner focus group will allow researchers to design questions that can measure a broader set of landowners' experiences in a future mailed questionnaire.

This study was the preliminary steps in forming a questionnaire. Since very little is known about what landowners view as a successful timber transaction, this project first used the method of focus group interviewing. Focus group interviews allowed this research team to gain a deeper understanding of what landowners' view as a successful timber transaction. Information learned from the focus group also helped define and support the models created that help explain the timber transaction process.

The timber transaction process is very complex. The use of focus groups helped in defining this process. Each landowner started out with a reason for selling timber. These reasoning's ranged from: clearing property for a house, salvaging timber that had been cut by oil and gas companies, conditions of a will, treating timber as a crop, awareness that trees needed to be cut at some point, and insect damage to trees. Once landowners' decided to sell timber they contacted people about selling and harvesting timber. Each landowner made preparations for the timber sale, but some had greater knowledge in who and how to contact different people. After arrangements for the timber sale were completed all the landowners' experienced the timber harvesting phase of the timber 
transaction process. Some of these landowners had a great experience while others felt cheated or disappointed.

The focus group was designed to bring out landowners experience's during the timber transaction process. Questions were asked to capture all aspects of the timber transaction process. After going through the transcripts from the landowner focus group, five main themes were found to influences landowners experiences. These themes include: Decision, People, Knowledge, Legal Aspect, and Trust. The most influential theme that influenced landowners' success and experience was Knowledge. Landowners who were informed and educated about selling timber knew who to contact first, which then played a big role in the legal and trust aspect landowners faced during the timber transaction process. The informed landowner had an overall more positive experience than those who were uniformed about selling timber.

\section{Recommendations for Practice}

As stated before this project was conducted in two phases. The themes that were found to influence landowners' experiences during the timber transaction process will help design questions around these themes to help capture landowners' experiences in a future mailed questionnaire. The information gathered from the landowner focus group can also be used in education and outreach programs designed to inform future landowners about selling timber. It was found that landowners' level of knowledge about timber transactions had the greatest impact on landowners' experience. Knowledge has also been proven to increase landowners' engagement with silviculture and Best Management Practices (Germain et al., 2014). These landowners' also stated that they 
either did not know where to look for information or information was very hard to find about selling timber. This shows the need for better methods of reaching these landowners'. Some landowners suggested using commercials or mailed letters that are designed to guide landowners to take the proper steps when it comes time for them to sell timber.

One limitation in reaching out to these landowners is that most never think about selling timber prior to their desire or need to do so. Kittredge (2004) says, "Family land might run in the background, and owners think of it when they need to or when they visit" (p.16). There is very helpful information on the WVDOF website about different programs and people that can guide landowners through the timber transaction process. Our goal and job as people in the forestry business should be to reach out and inform as many future landowners as possible that are thinking about selling timber. It is recommended that current programs and outreach should be examined to see if more can be accomplished by different techniques in order to inform future landowners about selling timber.

\section{Recommendations for Future Research}

Recruitment postcards and a cover letter were mailed to 400 family forest owners from five counties surrounding Morgantown, WV. This method of recruiting participants proved to be successful mainly because of the need of having between five to ten participants to hold a focus group. Due to the time constraint of this project only one focus group was conducted with landowners. Future recommendations for conducting research using focus groups would be to have several, with landowners from all regions 
of West Virginia. This would allow researchers to see if different focus groups with the same sample population from different regions yields the same or different results. This research team learned that three to four questions were sufficient for a focus group. Our research team designed nine questions (See Appendix D) for the landowner focus group but, only had time to ask three out of the nine. Even though all the questions were not asked during the focus group, all aspects of the timber transaction process were covered. This is a benefit of using focus groups. Once landowners started talking about their timber sale they described the entire process without the researcher having to ask every question. It is also advisable to have a moderator that has no prior knowledge about the population and topic being studied. This prevents bias that may affect the outcome of the focus group. One last recommendation is to have the moderator politely guide the participants back to the research questions whenever the participants get off topic. It was observed that the participants in the landowner focus group got off topic numerous occasions. The use of focus groups proved to be very successful in capturing landowners' experiences and can be used in any field of research that needs to capture a certain population's experiences or beliefs.

The overall goal of this study was to help aid in the development of a future questionnaire designed to capture family forest owners' experiences during timber transactions. Five main themes were found to have an effect on family forest owners experience during the timber transaction process. These themes include: Decision, People, Knowledge, Legal Aspect, and Trust. Questions can be designed around these themes in an effort to capture a wider range of family forest owners' experiences in a future mailed questionnaire. 


\section{References}

Andreasen, A. R. (1995). Marketing social change. Jossey-Bass.

Ary, D., Jacobs, L. C., Sorensen, C. K., \& Walker, D. (2013). Introduction to research in education. Cengage Learning.

Barraclough, S., \& Rettie, J. (1950). The ownership of small private forestland holdings in 23 New England towns. Station Paper. Northeastern Forest Experiment Station, (34).

Bengston, D., Asah, S., \& Butler, B. (2011). The diverse values and motivations of family forest owners in the United States: An analysis of an open-ended question in the National Woodland Owner Survey. Small-Scale Forestry, 10(3), 339-355.

Bliss, J. (2008). Family Forest Owners. Forest Community Connections: Implications for Research, Management, and Governance, 205.

Butler, B. (2008). Family forest owners of the United States, 2006: A technical document supporting the Forest Service 2010 RPA assessment. United States Department of Agriculture, Forest Service, Northern Research Station.

Butler, B. (2012). Family Forest Owners of the United States. Presentation. http://www.fs.fed.us/cooperativeforestry/frcc/brett_butler_frcc.pdf.

Butler, B. J., Tyrrell, M., Feinberg, G., VanManen, S., Wiseman, L., \& Wallinger, S. (2007). Understanding and reaching family forest owners: lessons from social marketing research. Journal of Forestry, 105(7), 348-357.

Butler, B., \& Leatherberry, C. (2004). America's family forest owners. Journal of Forestry, 102(7), 4-14.

Butler, B., \& Ma, Z. (2011). Family forest owner trends in the Northern United States. Northern Journal of Applied Forestry, 28(1), 13-18.

Butler, B., Leatherberry, C., \& Williams, S. (2005). Design, implementation, and analysis methods for the National Woodland Owner Survey.

Cardis, P. (2005). If you can't give me all 6's. Professional Builder, 70(9), 69-70.

Retrieved from https://search.proquest.com/docview/194240406?accountid=2837

Cengiz, E. (2010). Measuring customer satisfaction: must or not. Journal of Naval Science and Engineering, 6(2), 76-88. 
Childs, R. A. (2005). West Virginia's forests: growing West Virginia's future. Bureau of Business and Economic Research, College of Business and Economics, West Virginia University.

Demchik, M., Conrad, J., \& Vokoun, M. (2016). The scale and cost of seasonal timber harvesting restrictions in Wisconsin. Stevens Point (WI): Final Report for the Wisconsin Forest Practices Study.

Dennis, D. F. (1989). An economic analysis of harvest behavior: integrating forest and ownership characteristics. Forest Science, 35(4), 1088-1104.

Dickinson, B., \& Butler, B. (2013). Methods for estimating private forest ownership statistics: Revised methods for the USDA Forest Service's National Woodland Owner Survey. Journal of Forestry, 111(5), 319-325.

Dooley, K. E. (2007). Viewing Agricultural Education Research through a Qualitative Lens. Journal of Agricultural Education, 48(4), 32-42.

Dutka, A. F. (1995). AMA handbook for customer satisfaction. NTC Business books.

Earl, J. E., Harper, E. B., Hocking, D. J., Osbourn, M. S., Rittenhouse, T. A., \& Semlitsch, R. D. (2016). Effects of timber harvest on small mammal captures in experimental forestry plots.

Germain, R. H., Ellis, B., \& Stehman, S. V. (December 2014). Does Landowner Awareness and Knowledge Lead to Sustainable Forest Management? A Vermont Case Study. Journal of Extension, 52(2). Retrieved February 27, 2017, from https://www.joe.org/joe/2014december/rb3.php.

Gill, P., Stewart, K., Treasure, E., \& Chadwick, B. (2008). Methods of data collection in qualitative research: interviews and focus groups. British dental journal, 204(6), 291-295.

Glaser, B. G. (1965). The constant comparative method of qualitative analysis. Social problems, 12(4), 436-445.

Glaser, B. G., \& Strauss, A. L. (2009). The discovery of grounded theory: Strategies for qualitative research. Transaction publishers.

Gordon, R., McDermott, L., Stead, M., \& Angus, K. (2006). The effectiveness of social marketing interventions for health improvement: what's the evidence? Public health, 120(12), 1133-1139

Gorton, G. (2013). Some Reflections on the Recent Financial Crisis. Trade, Globalization and Development: Essays in Honour of Kalyan K. Sanyal, 161.

Gramann, J. H., Marty, T. D., \& Kurtz, W. B. (1985). A logistic analysis of the effects of beliefs and past experience on management plans for nonindustrial private forests. Journal of Environmental Management, 20:347-356. 
Havemann, J. (2008). The Financial Crisis of 2008: Year In Review 2008. (2016). In Encyclopedia Britannica. Retrieved from http://www.britannica.com/topic/Financial-Crisis-of-2008-The-1484264

Hill, N. (1996). Handbook of customer satisfaction measurement, Gower Publishing, Hampshire.

Jickling, M. (2009). Causes of the financial crisis.

Joshi, S., \& Arano, K. G. (2009). Determinants of private forest management decisions: a study on West Virginia NIPF landowners. Forest Policy and Economics, 11(2), 118-125.

Kärhä, K. (2004). Predicting Forest Owners Timber-selling Satisfaction. In of the Biennial Meeting of the Scandinavian Society of Forest Economics Vantaa, Finland, 12th-15th May, 2004 Heikki Pajuoja and Heimo Karppinen (eds.) Vantaa (p. 169).

Kärhä, K., \& Oinas, S. (1998). Satisfaction and company loyalty as expressed by nonindustrial private forest owners towards timber procurement organizations in Finland. Silva Fennica, 32, 27-42.

Kiess-Moser, E. (1989). Customer satisfaction. Canadian Business Review, 16(2), 43-45. Retrieved from https://search.proquest.com/docview/220677382?accountid=2837

Kilgore, M. A., Greene, J. L., Jacobson, M. G., Straka, T. J., \& Daniels, S. E. (2007). The influence of financial incentive programs in promoting sustainable forestry on the nation's family forests. Journal of Forestry, 105(4), 184-191.

Kilgore, M. A., Snyder, S. A., Eryilmaz, D., Markowski-Lindsay, M. A., Butler, B. J., Kittredge, D. B., ... \& Andrejczyk, K. (2015). Assessing the Relationship between Different Forms of Landowner Assistance and Family Forest Owner Behaviors and Intentions. Journal of Forestry, 113(1), 12-19.

Kingsley, N. P., Brock, S. M., \& DeBald, P. S. (1988). Focus group interviewing applied to retired West Virginia nonindustrial private forest landowners. Northern Journal of Applied Forestry, 5(3), 198-200.

Kittredge, D. B. (2004). Extension/outreach implications for America's family forest owners. Journal of Forestry, 102(7), 15-18.

Kurtz, W. B., \& Lewis, B. J. (1981). Decision-making framework for nonindustrial private forest owners: an application in the Missouri Ozarks. Journal of Forestry, 79(5), 285-288.

Landefeld, M., \& Schumacher, S. (October 2006). Timber Harvest Management Workshop. Timber Harvest Management Workshop, 44. Retrieved February 19, 2017, from https://joe.org/joe/2006october/tt4.php. 
Leffler, K. B., \& Rucker, R. R. (1991). Transactions Costs and the Efficient Organization of Production: A Study of Timber-Harvesting Contracts. Journal of Political Economy, 99(5), 1060-1087.

Lincoln, Y. S., \& Guba, E. G. (1985). Naturalistic inquiry (Vol. 75). Sage.

Maigret, T. A., Cox, J. J., Schneider, D. R., Barton, C. D., Price, S. J., \& Larkin, J. L. (2014). Effects of timber harvest within streamside management zones on salamander populations in ephemeral streams of southeastern Kentucky. Forest Ecology and Management, 324, 46-51.

Mance, K., Sills, E., \& Warren, S. (2004, March). Outreach to limited resource forest landowners: Extension innovation for low literacy audiences. In Human Dimensions of Family, Farm, and Community Forestry International Symposium. Washington State University, Pullman.

Mason, M. (2010, August). Sample size and saturation in $\mathrm{PhD}$ studies using qualitative interviews. In Forum qualitative Sozialforschung/Forum: qualitative social research (Vol. 11, No. 3).

McGill, D. W., Magill, D. J., Kochenderfer, J., Ford, W. M., \& Schuler, T. (2006). Information transfer during the timber transaction period in West Virginia. USA.

McGill, D. W., Pierskalla, C. D., Jennings, B. M., Grushecky, S. T., \& Lilly, D. (2006). Landowner satisfaction with timber harvesting on West Virginia forest stewardship program properties. Northern Journal of Applied Forestry, 23(1), 610.

Merriam, S. B. (2009). Qualitative research: A guide to design and implementation: Revised and expanded from qualitative research and case study applications in education. San Franscisco: Jossey-Bass.

Mishkin, F. S. (2010). Over the cliff: From the subprime to the global financial crisis (No. w16609). National Bureau of Economic Research.

Moss, S. A. (2011). The silvicultural and economic impact of professional forestry assistance on timber harvests on non-industrial, private forestland in West Virginia. Morgantown, W. Va: West Virginia University Libraries.

Moss, S. A., \& Heitzman, E. (2012, March). IMPACT OF PROFESSIONAL FORESTERS ON TIMBER HARVESTS ON WEST VIRGINIA NONINDUSTRIAL PRIVATE FORESTS. In 18th Central Hardwood Forest Conference (Vol. 117, p. 390).

Nix, S. (n.d.). How Smokey Bear has saved millions of acres of forests from fire. Retrieved November 15, 2015, from http://forestry.about.com/cs/smokeybear/a/Smokey_50years.htm

Northern Research Station. (2008). Who owns America's forests? Forest ownership patterns and family forest highlights from the National Woodland Owner Survey. U.S. Department of Agriculture, Forest Service, Northern Research Station. 
Nyer, P. (1999). Cathartic complaining as a means of reducing consumer dissatisfaction. Journal of Consumer Satisfaction, Dissatisfaction and Complaining Behavior, 12.

OLIVER, R. L.1987. An investigation of the interrelationship between consumer (dis) satisfaction and complaint reports. Advances in Consumer Research, Edited by Melanie Wallendorf and Paul Anderson, 14, 218-222.

Onwuegbuzie, A. J., Dickinson, W. B., Leech, N. L., \& Zoran, A. G. (2009). A qualitative framework for collecting and analyzing data in focus group research. International journal of qualitative methods, 8(3), 1-21.

Payer, D. C., \& Harrison, D. J. (1999). Influences of timber harvesting and trapping on habitat selection and demographic characteristics of marten. Final contract report to Maine Department of Inland Fisheries and Wildlife, Orono, Me.

Ritchie, J., \& Lewis, J. (2003). Qualitative Research Practice: A guide for Social Science Students and Researchers.

Rogers, E. M. (2010). Diffusion of innovations. Simon and Schuster.

Silver, E. J., Leahy, J. E., Weiskittel, A. R., Noblet, C. L., \& Kittredge, D. B. (2015). An evidence-based review of timber harvesting behavior among private woodland owners. Journal of Forestry, 113(5), 490-499.

Stein, S., McRoberts, R., Mahal, L., Carr, M., Alig, R., Comas, S., \& Cundiff, A. (2009). Private forests, public benefits: increased housing density and other pressures on private forest contributions. General Technical Report-Pacific Northwest Research Station, USDA Forest Service, (PNW-GTR-795).

Stelzer, H. (2015). Selling Timber: What the Landowner Needs to Know. University of Missouri Extension.

Syed, Saad Andaleeb, and Carolyn Conway. "Customer Satisfaction in the Restaurant Industry: An Examination of the Transaction-Specific Model." The Journal of Services Marketing 20.1 (2006): 3-11. ProQuest. Web. 23 Jan. 2017

Szymanski, D. M., \& Henard, D. H. (2001). Customer satisfaction: A meta-analysis of the empirical evidence. Journal of the academy of marketing science, 29(1), 1635.

Tracy, S. J. (2010). Qualitative quality: Eight "big-tent" criteria for excellent qualitative research. Qualitative inquiry, 16(10), 837-851.

Weinreich, N. K. (2006). Integrating quantitative and qualitative methods in social marketing research. Retrieved April, 27, 2008.

Weinreich, N. K. (2006). What is social marketing. Weinreich Communications, 10. 
West Virginia Division of Forestry (WVDOF). (2010). WEST VIRGINIA STATEWIDE FOREST RESOURCE ASSESSMENT. Retrieved March 18, 2017, from http://www.wvforestry.com/DOF100Assessment_Revised_091310_Part1.pdf

Widmann, Richard H. 2014. Forests of West Virginia, 2013. Resource Update FS-22. Newtown Square, PA: U.S. Department of Agriculture, Forest Service, Northern Research Station. 4 p.

Widmann, Richard H.; Cook, Gregory W.; Barnett, Charles J.; Butler, Brett J.; Griffith, Douglas M.; Hatfield, Mark A.; Kurtz, Cassandra M.; Morin, Randall S.; Moser, W. Keith; Perry, Charles H.; Piva, Ronald J.; Riemann, Rachel; Woodall, Christopher W. 2012.West Virginia's Forests 2008. Resour. Bull. NRS-61 Newtown Square, PA: U.S. Department of Agriculture, Forest Service, Northern Research Station

Young, R. A., \& Reichenbach, M. R. (1987). Factors influencing the timber harvest intentions of nonindustrial private forest owners. Forest Science, 33(2), 381-393. 


\section{Appendix A: Recruitment Cover-Letter}

November 28, 2016

Dear West Virginia Woodland Owner:

Logging decisions that landowners make affect the health and long-term productivity of the state's natural resources. We are writing to ask for your help in improving our understanding of woodland owners logging experiences. Your input will help forestry professionals inform West Virginia woodland owners about successful and satisfactory logging practices. We hope you will complete the enclosed pre-stamped postcard and share the successes and challenges you have experienced during any recent logging on your property.

At the end of the postcard is an option to participate in a focus group interview in or near Morgantown WV. We are offering a $\$ 50$ pre-paid VISA ${ }^{\circledR}$ gift card for those selected to participate. Individuals selected for the focus group will be contacted by telephone or email. The focus group interview is designed to gather a deeper understanding of landowners' experiences with different people, equipment, and logistics involved during the full logging process. There are three dates that you can choose from for the focus group interview January $12^{\text {th }}, 13^{\text {th }}$, or $14^{\text {th }}$. Please specify on the postcard which of these three dates you would be available to meet.

Participation in this study is completely voluntary and all information you provide will be held as confidential as possible. You may skip any question and can stop at any time, but please return the postcard.

The postcard is pre-addressed and posted, so just fill it out and drop it in any mailbox! Please return the completed questionnaire by December $9^{\text {th }} 2016$.

If you have any questions or concerns about the postcard, please contact Dave McGill at 304-293-5930 or dmcgill@wvu.edu

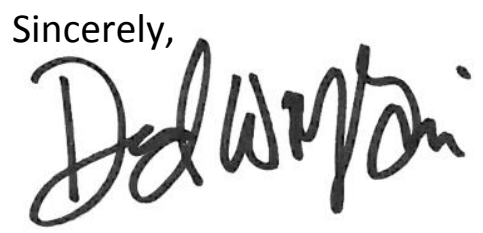

Dave McGill

WVU Extension Forester

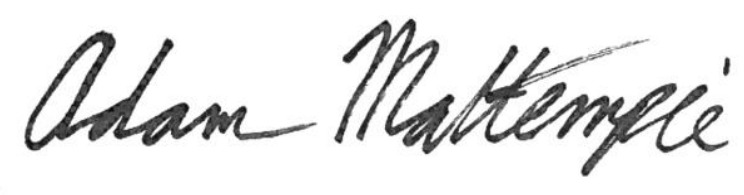

Adam Maltempie Graduate Research Assistant 


\section{Appendix B: Recruitment Postcard}

West Virginia Woodland Owner Survey
Please answer as many questions as you can:

In what year did you most recently have your property logged?

Do you live on this property? Yes $\square$ No $\square$

How satisfied were you after you had your property logged? (check one)

Not at all $\square$ Slightly $\square$ Moderately $\square$ Very $\square$ Extremely $\square$

Was there a forester involved? Yes $\square$ No $\square$ Not Sure $\square$

Why did you have your property logged?

If you are willing to participate in a local afternoon "focus group" to meet other landowners and share more of your logging experience, please fill out the following:

Name: Phone \#:

Email: Dates available (circle one) Jan $1213 \quad 14$

Thank you for your help on this important project!

For more info contact Project Coordinator Dr. Dave McGill (dmcgill@wvu.edu or 304-293-5930). 


\section{Appendix C: Reminder/Thank You Letter}

Date

Name

Address

City, State, Zip

Dear,

We would like to personally thank you for volunteering your time and sharing your expertise at the upcoming West Virginia Woodland Owner focus group. The focus group will be held at the Morgantown Ramada Inn on Thursday, January $12^{\text {th }}$ at $1 \mathrm{pm}$. The Ramada Inn is located just off the Interstate 68, Exit 1 . This event will last approximately two hours, and refreshments will be provided.

During the focus group, we will be asking a short number of questions to bring out your experiences as woodland owners working with different people, equipment, and logistics during the full logging process. This will allow us to better understand what creates a successful logging experience and to promote these ideas among woodland owners interested in future logging.

Once again, thank you for agreeing to participate in this focus group. This research would not be possible without your help. If you have any further questions, please feel free to contact us (contact information provided below).

Sincerely,

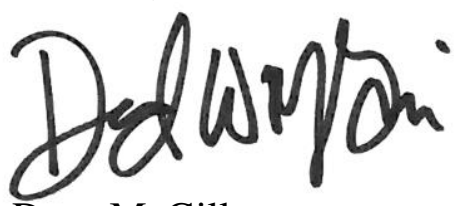

Dave McGill

WVU Extension Forester

304-293-5930

dmcgill@wvu.edu

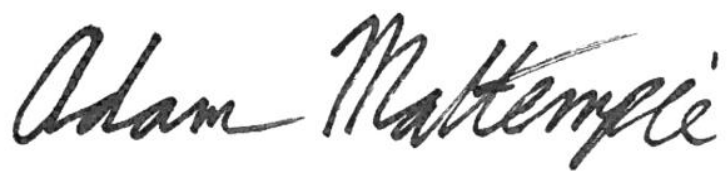

Adam Maltempie

Graduate Research Assistant

304-228-5122

apmaltempie@mix.wvu.edu 


\section{Appendix D: Focus Group Questions}

\section{Questions}

1. Why did you decide to sell your timber?

- What did you hope to get out of the selling of your timber?

i. Did you get that to the level that you thought you would?

1. Why/why not?

a. Is there one person responsible for making that happen or not happen?

2. When you were making the decision to sell timber...

- Did you have any concerns about what might go on in the process of timbering?

- What were you most looking forward to during the timbering process?

3. From the beginning to the end of the process of selling and harvesting your timber, who was involved and what were their roles?

- How much did you interact with the different people involved in the timbering process?

4. Is there something missing from the process? Or redundant in what you see as the timbering process?

5. What were some of the problems that occurred during the timber harvest?

- If this problem could have been foreseen, how might it have been minimized?

6. What were some of the most positive experiences during the timbering process?

7. If we were to ask the other people involved in your timbering process what they thought were the best and worst aspects of the timbering on your property were, what would they be?

8. What were your thoughts about the overall timbering process after all the loggers and foresters left?

9. Was your overall experience with timbering/logging successful? Why? Why not?

- Is there one person that is most responsible for that success or lack of success? 


\section{Appendix E: Demographic Background Questions}

\section{DEMOGRAPHIC INFORMATION}

1. Gender?

2. Year you were born?

3. Current occupation?

4. What is the highest level of education that you have completed?

$\square$ GED

$\square$ Some High school

$\square$ Completed High School

$\square$ Some College

$\square$ Completed College

$\square$ Graduate or professional school after college

5 . What is your average yearly income?

$\square$ Less than $\$ 25,000$

$\square \$ 25,001-\$ 50,000$

$\square \$ 50,001-\$ 75,000$

$\square \$ 75,001-\$ 100,000$

$\square \$ 100,001-\$ 200,000$

$\square \$ 200,000$

How many acres of land do you own? acres 